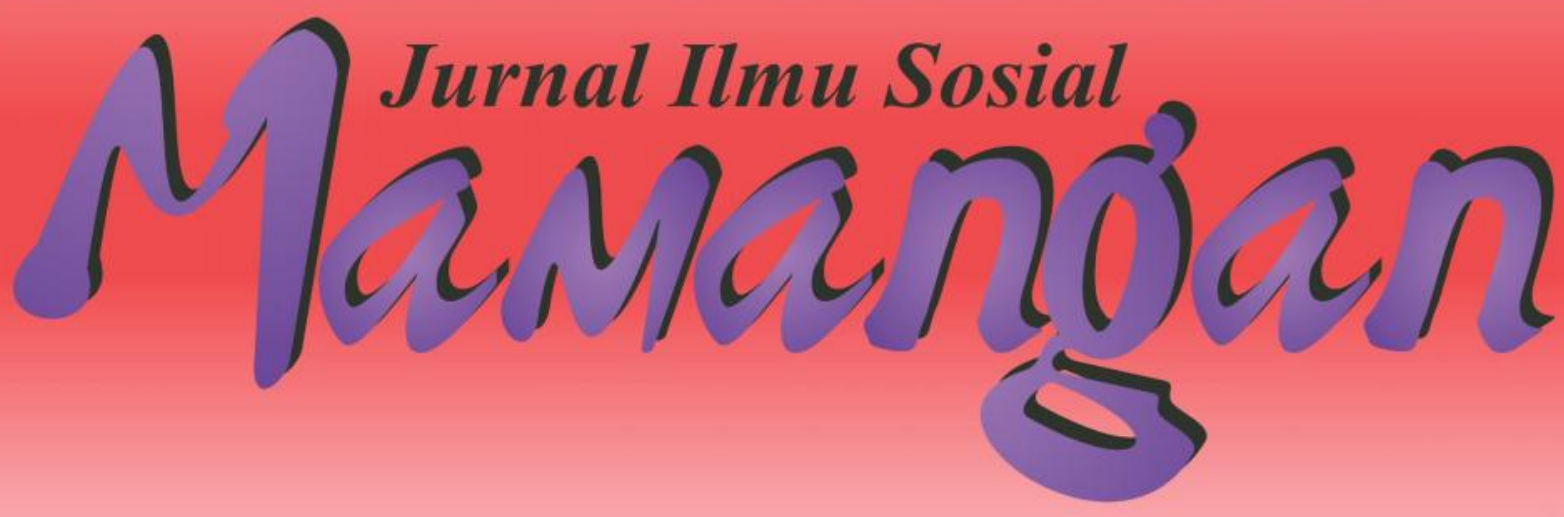

Diamika Perempuan Pedagang Makanan Di Sicincin

Elsa melia Roza, Yulkardi \& Rinel Fitlayeni

Motivasi \& Strategi Keluarga Miskin Nagari Talu, Kab. Pasaman Barat Melanjutkan Pendidikan Anak Ke Perguruan Tinggi

Cici Rahma Sari, Elvawati \& Dian Kurnia Anggreta

Dampak Sosial Ekonomi Objek Wisata The Unique Park Waterboom Di Kota Sawahlunto

Lisa Desatria, Fachrina \& Faishal Yasin

Pandangan Rumah Tangga Sasaran (RTS) Terhadap Pelaksanaan Dana Bergulir PNPM-MP Di Kelurahan Balai Gadang, Kota Padang Elparianti, ArdiAbbas \& Elvawati

Kehidupan Waria Di Jorong Mandiangin, Kecamatan Kinali, Kabupaten Pasaman Barat

Susanki \& Dian Anggraini Oktavia

Fungsi Koperasi Serba Usaha Ekonomi Desa (KSU-ED) Terhadap Masyarakat Nagari Tabek Talang Babungo, Kabupaten Solok Yenti Welia, Witrianto \& Refni Yulia 


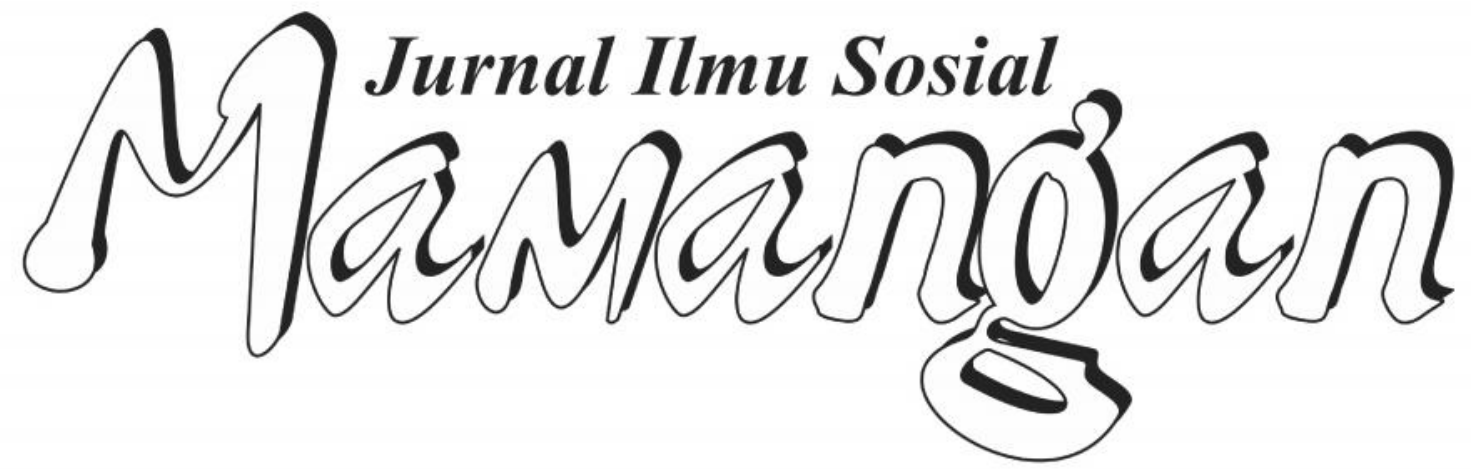




\section{Mitra Bestari}

Prof. Dr. Afrizal, MA. (FISIP, Unand Padang)

Dr. A. Latief Wiyata, M. Si. (Universitas Jember, Jember)

Prof. Dr. Badaruddin, M. Si. (FISIP, USU Medan)

Dr. Fikarwin Zuska, M. Si. (FISIP, USU Medan)

Nurus Shalihin, M. Si., Ph.D. (Fak. Ushuluddin IAIN Imam Bonjol Padang)

Dr. Semiarto A. Purwanto, M. Si. (FISIP, UI Jakarta)

Dr. Wahyu Wibowo, M. Si. (Universitas Nasional, Jakarta)

\section{Dewan Redaksi}

Dr. Zusmelia, M. Si.

Dr. Maihasni, M. Si.

Adiyalmon, S. Ag., M. Pd.

Firdaus, S. Sos., M. Si.

\section{Pemimpin Redaksi}

Firdaus, S. Sos., M. Si.

\section{Anggota Redaksi}

Dian Kurnia Anggreta, S. Sos., M. Si.

Rinel Fitlayeni, S. Sos., MA.

Surya Prahara, SH.

ISSN: 2301-8496

\section{Alamat Redaksi:}

Laboratorium Program Studi Pendidikan Sosiologi, STKIP PGRI Padang

Jl. Gunung Pangilun, Padang

Email: redaksimamangan@yahoo.com

Penerbit :

Program Studi Pendidikan Sosiologi, STKIP PGRI Padang

\section{Contac person :}

Firdaus (Hp. 085263881221/Email : daus gila@yahoo.com) 


\section{DAFTAR ISI}

Diamika Perempuan Pedagang Makanan Di Sicincin

Elsa melia Roza, Yulkardi \& Rinel Fitlayeni.

Motivasi \& Strategi Keluarga Miskin Nagari Talu, Kab. Pasaman Barat Melanjutkan Pendidikan Anak Ke Perguruan Tinggi

Cici Rahma Sari, Elvawati \& Dian Kurnia Anggreta.

Dampak Sosial Ekonomi Objek Wisata The Unique Park Waterboom Di Kota Sawahlunto

Lisa Desatria, Fachrina \& Faishal Yasin

Pandangan Rumah Tangga Sasaran (RTS) Terhadap Pelaksanaan Dana Bergulir PNPM-MP Di Kelurahan Balai Gadang, Kota Padang

Elparianti, Ardi Abbas \& Elvawati

Kehidupan Waria Di Jorong Mandiangin, Kecamatan Kinali, Kabupaten Pasaman Barat

Susanki \& Dian Anggraini Oktavia

Fungsi Koperasi Serba Usaha Ekonomi Desa (KSU-ED) Terhadap Masyarakat Nagari Tabek Talang Babungo, Kabupaten Solok 


\title{
PANDANGAN RUMAH TANGGA SASARAN (RTS) TERHADAP PELAKSANAAN DANA BERGULIR PNPM-MP DI KELURAHAN BALAI GADANG, KOTA PADANG
}

\author{
Elparianti ${ }^{1}$, Ardi Abbas ${ }^{2}$, Elvawati ${ }^{3}$ \\ ${ }^{1 \& 3}$ Sekolah Tinggi Keguruan dan Ilmu Pendidikan (STKIP) PGRI Sumatera Barat \\ 2 Universitas Andalas
}

\begin{abstract}
This article background is information about the data differences between statistically and realities in society about PNPM-MP Programe. Statistically PNPM-MP is considered good enough in the effort to reduce poverty have been able to reduce the number of target households in the Balai Gadang, but the reality in the field are still many poor people. In general view of the target households are not re-categorized as the objectives of the program provides pastures that show received a position as a party that can not accept a revolving fund, As for the efforts made by the PNPM-MP after the target households are not back to being targeted by inviting households to be targeted to training events associated with increased economic cooperation with the family and other financial institutions greater. As for the view of the target households on the implementation of the revolving fund PNPM-MP in the fight against poverty can be concluded that in general the target households provide a positive outlook for feel that the borrowing of funds on a rolling basis from PNPM-MP, especially for households sesaran the installment lending smoothly and has had previous attempts
\end{abstract}

\section{Keywords : Household Goals, PNPM-MP Revolfing Fund, Poverty}

\begin{abstract}
ABSTRAK
Artikel ini dilatarbelakangi oleh adanya perbedaan informasi antara data secara statistik dengan realitas yang ada dalam masyarakat. secara statistik pelaksanaan PNPM-MP dinilai cukup baik dalam upaya menanggulangi kemiskinan telah mampu menurunkan jumlah rumah tangga sasaran (RTS) di Kelurahan Balai Gadang, namun realitasnya dilapangan masih banyak masyarakat misikin. Secara umum pandangan rumah tangga sasaran (RTS) tidak kembali terkategori sebagai sasaran pelaksanaan program yaitu RTS memberikan padangan yang menunjukkan menerima posisi sebagai pihak yang sudah tidak bisa menerima dana bergulir, adapun upaya yang dilakukan oleh pihak pelaksanaan PNPM-MP setelah RTS tidak kembali menjadi sasaran dengan mengundang RTS ke acara pelatihan yang berhubungan dengan peningkatan ekonomi keluarga dan melakukan kerjasama dengan lembaga keuangan lain yang lebih besar. Sedangkan untuk pandangan RTS terhadap pelaksanaan dana bergulir PNPM-MP dalam upaya penanggulangan kemiskinan dapat disimpulkan bahwa secara umum RTS memberikan pandangan positif karena merasa terbantu dengan adanya peminjaman dana secara bergulir dari PNPM-MP terutama bagi RTS yang angsuran peminjamannya lancar dan telah memiliki usaha sebelumnya.
\end{abstract}

Kata Kunci: Rumah Tangga Sasaran, Dana Bergulir PNPM-MP, Kemiskinan

Jurnal Ilmu Sosial Mamangan, Volume II Nomor 2, juli-Desempber 2013 | 92 


\section{PENDAHULUAN}

Masalah

kemiskinan

sangat membutuhkan perhatian semua pihak secara bersama dan terkoordinasi dengan baik dalam rangka penanggulangannya, penanganan selami ini cendrung dilaksanakan secara parsial dan tidak berkelanjutan. Hal ini disebabkan karena banyak pihak bagi masyarakat dalam hal pemberdayaan dan pemecahan dalam permasalahan kemiskinan. Untuk meningkatkan efektifitas penanggulangan kemiskinan tersebut pemerintah meluncurkan Program Nasional Pemberdayaan Masyarakat yang dikenal dengan PNPM Mandiri pada tahun 2007, melalui PNPM Mandiri ini dirumuskan kembali penanggulangan kemiskinan secara sistematik seperti yang diharapkan. Masyarakat ditempatkan bukan sebagia objek dari penanggulangan kemiskinan tersebut. Masyarakat mulai dilibatkan dari tahap perencanaan, pelaksanaan hingga pemantuan dan evaluasi (Kementrian Pekerjaan Umum, 2007).

Pelaksanaan PNPM Mandiri pada tahun 20017 dimulai dengan program pemberdayaan masyarakat, yaitu Program Pengembangan Kecamatan (PPK) sebagai dasar pemberdayaan masyarakat diperdesaan yang sekarang dinamakan PNPM Mandiri Perdesaan dan Program Penanggulangan Kemiskinan di Perkotaan (P2KP) sebagai dasar pengembangan masyarakat di perkotaan yang sekarang dinamakan PNPM Mandiri Perkotaan.

Program ini sangat strategis karena menyiapkan landasan kemandirian masyarakat yang representatif, mengakar dan kondusif bagi pengembangan modal sosial masyarakat, sehingga dimasa yang akan datang masyarakat dapat menyiapkan secara efekti program masyarakat jangka menengah dalam penanggulangan kemiskinan yang menjadi pengikat dalam kemitraan masyarakat dengan pemerintah daerah dan kelompok peduli setempat (Kementrian Pekerjaan Umum, 2010).

Provinsi Sumatera Barat merupakan salah satu provinsi yang menjadi sasaran pelaksanaan PNPM Madiri Perkotaan dengan cakupan wilayah dampingan 10 Kabupaten dan Kota, 23 Kecamatan, 204 Kelurahan. Pelaksanaan ini dimulai pada tahun 2008, dalam pelaksanaannya akan berakhir pada tahun 2014 dengan jumlah penduduk miskin sebanyak 441.799 jiwa yang tersebar keseluruhan Kabupaten dan Kota yang ada di Provinsi Sumatera Barat.

Kota Padang merupakan salah satu wilayah yang ada di Privinsi Sumatera Barat yang menjadi sasaran pelaksanaan PNPM MP sejak tahun 2008. Berdasarkan data dari Pendataan Program Perlindungan Sosial (PPLS) tahun 2011 penduduk miskin Kota Padang adalah $33.505 \mathrm{KK}$ atau 170.812 Jiwa. (BPS, 2011) Dapat dilihat pada tabel dibawah ini.

Tabel 1

Rumah Tangga Sasaran (RTS) Kota Padang

\begin{tabular}{|l|l|c|}
\hline No & Kecamatan & Jumlah KK \\
\hline 1 & Padang Barat & 1.991 \\
\hline 2 & Padang Timur & 2.949 \\
\hline 3 & Padang Utara & 1.475 \\
\hline 4 & Padang Selatan & 3.038 \\
\hline 5 & Koto Tangah & 6.935 \\
\hline 6 & Nanggalo & 1.689 \\
\hline 7 & Kuranji & 5.190 \\
\hline 8 & Pauh & 2,568 \\
\hline 9 & Lubuk Kilangan & 1,462 \\
\hline 10 & Lubuk Begalung & 4.017 \\
\hline 11 & Bungus Teluk Kabung & 2.191 \\
\hline \multicolumn{2}{|c|}{ Jumlah } & $\mathbf{3 3 . 5 0 5}$ \\
\hline
\end{tabular}

Sumber: Padang Dalam Angka 2011

Berdasarkan tabel diatas terlihat Kecamatan Koto Tangah merupakan Kecamatan yang memeliki persentase jumlah penduduk miskin dibandingkan dengan 10 Kecamatan lainnya. Kecamatan Koto Tangah memiliki 13 Kelurahan dan jumlah rumah tangga sasaran, berikut data PPLS pada tahun 2011.

Tabel 2

Rumah Tangga Sasaran (RTS) Kecamatan Koto Tangah

\begin{tabular}{|l|l|c|}
\hline No & \multicolumn{1}{|c|}{ Kelurahan } & Jumlah KK \\
\hline 1 & Aia Pacah & 548 \\
\hline 2 & Balai Gadang & 1.055 \\
\hline 3 & Batang Kabung & 244 \\
\hline 4 & Batipuh Panjang & 900 \\
\hline 5 & Bungo Pasang & 337 \\
\hline 6 & Dadok Tunggul Hitam & 392 \\
\hline 7 & Koto Panjang Ikua Koto & 392 \\
\hline 8 & Koto Pulai & 151 \\
\hline 9 & Lubuak Buayo & 277 \\
\hline 10 & Lubuk Minturun & 691 \\
\hline
\end{tabular}




\begin{tabular}{|c|l|c|}
\hline 11 & Padang Sarai & 731 \\
\hline 12 & Parupuak Tabing & 675 \\
\hline 13 & Pasia Nan Tigo & 346 \\
\hline \multicolumn{2}{|c|}{ Jumlah } & $\mathbf{6 . 9 3 5}$ \\
\hline
\end{tabular}

Sumber: Litbang Kota Padang 2011

Berdasarkan data diatas terlihat Kelurahan Balai Gadang merupakan kelurahan yang memeliki angka tinggi kemiskinan di Kecamatan Koto Tangah. Berbagai kegiatan telah dilakukan oleh pihak kelurahan dengan berbagai program kerakyatan termasuk PNPM MP yang juga diprogramkan untuk menyelesaikan masalah kemiskinan. Adapun tujuan penelitian ini yaitu bagaimana rumah tangga sasaran terhadap pelaksanaan dana bergulir PNPM MP dalam upaya penanggulan kemiskinan?

\section{TINJAUAN PUSTAKA}

Dalam paradigma defenisi sosial menusia dipandang sebagai individu yang berfikir dan kreatif sehingga proses berfikir dan interpretasi individu terhadap sesuatu merupakan hal yang diteliti dalam prespektif ini. Interaksionisme simbolik adalah manusia saling menterjemahkan dan saling mendefenisikan tindakannya. Memandang bahwa tanggapan seseorang tidak dibuat secara langsung terhadap tindakan orang lain, tapi didasarkan atas "makna" yang diberikan terhadap tindakan orang lain (Ritzer \& Goodman, 2010)

Ada tiga terminologi kunci dari teori interaksionisme simbolik dalam memahami kehidupan sosial menurut Blumer (Poloma, 2010) Pertama, individu bertindak terhadap sesuatu berdasarkan makna-makna yang ada pada sesuatu itu bagi mereka, Kedua, makna tersebut berasal dari interaksi sosial seseorang dengan orang lain, Ketiga, maknamakna tersebut disempurnakan melalui proses sosial yang terjadi.

Dalam penelitian (Sukron, 2009) yang berjudul Pemberdayaan Masyarakat Untuk Mengurangi Kemiskinan melalui PNPM Mandiri, menyebutkan Progarm PNPM Mandiri telah diimplementasikan dengan mengacu pada konsep pemberdayaan parsipatoris, dimana masyarakat telah terlibat secara aktif dalam mengawal pelaksanaan program dimulai dari sosialisasi, refleksi, pemetaan dan pelaksanaan. Dalam usaha yang dilakukan untuk meningkatkan kesekahteraan masyarakat miskin malalui pengembangan usaha pinjaman dana bergulir bagi masyarakat. Dari pertumbuhan tingkat kemiskinan menunjukan angka yang positif, artinya terdapat penurunan angka kemiskinan selama 2 tahun terakhir yaitu rata-rata sebesar $0,18 \%$ dari usaha yang dilakukan.

Penelitian (Yulyanti, 2010) melihat implementasi program PNPM Mandiri belum maksimal ini dikarenakan baru mencapai angka 64,26\% dari angka maksimal yang diharapkan $75 \%$. Ketidakmaksimalan tersebut disebabkan bebapa faktor yaitu: Pertama, lambatnya pencairan dana pendampingan sehingga menghambat jalannya program dan mengakibatkan tumpang tindih pelaksanaan program pada periode berikutnya. Kedua, kepatuhan SDM terhadap prosedur yang telah ditetapkan dalam pelaksanaan PNPM Madiri kurang, terlihat dalam pelaksanaannya masih ada beberapa kasus penyelewengan peran dari masing-masing jabatan yang seharusnya hanya sebagai pembina, tetapi turut campur tangan dalam pengelolaan dana dan penentuan suplayer. Ketiga, tingkat kualitas SDM di Kecamatan Cadasari yang belum merata disetiap desa yang ikut melaksanakan PNPM Mandiri.

\section{METODE PENELITIAN}

Penelitian ini menggunakan metode kualitatif dengan tipe deskriptif. Lokasi penelitian ini di Kelurahan Balai Gadang Kecamatan Koto Tangan. Pemilihan informan mengunakan purposive (sengaja), metode pengumpulan data yaitu obsevasi non partisipan, wawancara mendalam, dan studi dokumen. Analisi data digunakan empat tahap yaitu pengumpulan data, reduksi data, penyajian data dan penarikan kesimpulan menurut Miles dan Huberman

\section{PANDANGAN RTS TERHADAP PELAK- SANAAN DANA BERGULIR PNPM-MP}

Sebelum PNPM-MP ada beberapa program penanggulangan kemiskinan yang telah dilaksanakan di Kelurahan Balai Gadang diantaranya, Raskin (beras untuk rakyat miskin), Subsidi BBM, Bantuan Langsung Tunai (BLT), Askeskin, Kredit Mikro Nagari, dan Koperasi Jasa Keuangan Syariah (KJKS). Serta untuk lebih 
mengintensifkan upaya penanggulangan kemiskinan tersebut, maka pada tahun 2009 PNPM-MP mulai dilaksanakan di Kelurahan Balai Gadang.

Proses awal pelaksanaan PNPM-MP di Kelurahan Balai Gadang diawali dengan musyawarah sosialisasi ditingkat kelurahan yang dihadiri oleh pihak kelurahan, ketua RT/RW setempat, tokoh masyarakat dan masyarakat, musyawarah dilakukan dikantor lurah Balai Gadang. Pada musyawarah sosialisasi ini fasilitator menjelaskan mengenai pelaksanaan program yang didampingi oleh penanggung jawab (PJOK), yang meliputi beberapa tahapan yaitu: penyebaran informasi, mempersiapkan masyarakat, refleksi kemiskinan, pemetaan swadaya, pembentukan lemabaga keswadayaan masyarakat, penyusunan pronangkis, dan pengorganisasian kelompok swadaya masyarakat.

Tahap pelaksanaan tersebut dilakukan pada tahun 2009, selanjutnya dasar kegiatan yang telah dirancang melalui PNPM-MP terletak pada kelompok-kelompok masyarakat. proses kegiatan semuanya berlangsung dalam masyarakat yang didampingi oleh para pendamping dan fasilitator kegiatan yang dimulai dari tahap perancanaan, pelaksanaan, monitoring dan evaluasi. Pemamfaatan bantuan PNPM-MP salah satunya dapat dipergunakan sebagai dana bergulir dengan melakukan aktifitas usaha ekonomi produktif. Usaha-usaha kecil yang berorientasi pada berbagai sektor perdagangan, kerajinan, industri, peternakan dan jasa yang dapat dilakukan oleh penerima.

Jenis-jenis kegiatan yang dilaksanakan PNPM-MP dikategorikan sebagai berikut: 1) kegiatan pendidikan masyarakat, 2) kegiatan kesehatan masyarakat, 3) kegiatan simpan pinjam untuk perempua, 4) kegiatan sarana prasarana, 5) peningkatan kapasitas kelompok usaha ekonomi.

Pelaksanaan PNPM-MP di Kelurahan Balai Gadang meliputi tiga aspek yaitu lingkugan, sosial dan ekonomi. Dari ketiga aspek terbeut yang berimplikasi terhadap Rumah Tangga Sasaran (RTS) adalah aspek ekonomi berupa simpan pinjam dana secara bergulir, ini dikarenakan sasaran langsung kepada KK miskin.

Pelaksanaan simpan pinjam dana bergulir bertujuan untuk menyediakan akses layanan keuangan kepada rumah tangga miskin dengan peminjaman mikro berbasis pasar dengan kegiatan yang menghasilkan pedapatan untuk memperbaiki kondisi ekonomi mereka. Disamping itu juga bertujuan membelajarkan mereka dalam hal mengelola pinjaman dan menggunakannya secara benar.

Syarat-syarat masyarakat untuk mendapatkan peminjaman adalah rumah tangga miskin yang terdata dalam pemetaan RTS, Minimal 30\% peminjam perempuan, telah menjadi anggota Kelompok Swadaya Masyarakat (KSM), dan akses pinjaman bagi KSM yang kinerja pengembalian baik terjamin keberlanjutannya.

Realisasi pemberian bantuak dalam bentuk dana Bantuan Langsung Masyarakat (BLM) tersebut meliputi enam tahap kegiatan yaitu: 1) pengajuan pinjaman, 2) pemeriksaan peminjaman, 3) putusan pinjaman, 4) realisasi pinjaman, 5) pembinaan pinjaman, 6) pembayaran pinjaman. Seluruh kegiatan dilaksanakan oleh fasilitator dan relawan masyarakat yang saling bekerjasama untuk merealisasikan dana bergulir dimasyarakat.

Di tingkat masyarakat proses penyaluran dana pencairan dana BLM dilaksanakan berdasarkan kelompok bukan perorangan (individu) yang meliputi tahapan sebagai berikut: memiliki usaha dan akan memulai usaha baru, pembentukan kelompok KSM, pembuatan proposal yang sesuai dengan anggota KSM, menyerahkan fotocopy KK, KTP, photo serta mengisi blangko yang telah disediakan oleh KLM, LKM kemudian akan menyeleksi kelayakan anggota KSM.

Kegiatan peminjaman ini sudah berjalan dengan baik yang dapat dilihat dari bentuk pengembalian peminjaman dari anggota KSM mencapai 95\%. Angka ini menunjukan keseriuasan KSM dalam memamfaatkan dana bergulir dari program PNPM-MP.

Pelaksanaan PNPM-MP dalam upaya menanggulangi kemiskinan sangat erat kaitannya dengan masyarakat yang dijadikan sebagai sasaran maupun yang sudah tidak menjadi sasaran dalam pelaksanaan program, keterkaitan tersebut salah satunya dapat dilihat dari pandangan atau persepsi yang diberikan masyarakat terhadap pelaksanaan program. 
Pandangan yang diberikan oleh RTS terhadap pelaksanaan PNPM-MP dalam upaya penanggulangan kemiskinan terutama dari aspek ekonomi berbeda-beda baik antara RTS yang memang merasakan manfaat dari pelaksanaan program secara langsung maupun tidak langsung. Oleh sebab itu penyajian dari pandangan yang diberikan RTS tersebut diklasifikasikan berdasarkan RTS yang memberikan pandangan yang merespon positif pelaksanaan program PNPM-MP dikategorikan sebagai berikut:

\section{KATEGORI RESPON POSITIF RTS.}

Banyak masyarakat yang merespon program yang dilaksanakan oleh PNPM-MP dalam bidang peminjaman dana bergulir bagi RTS dengan membentuk Kelompok Swadaya Masyarakat (KSM), dari proses peminjaman ini terlihat tidak mempersulit RTS dalam mendapatkan pinjaman dana, KSM hanya melakukan administrasi dan membayar Rp15.000. biaya ini merupakan jasa peminjaman yang dikenakan pada penerima bantuan sebesar 1,5\% dari total peminjaman tiap bulannya.

Dana peminjaman awal melalui kelomok KSM sebesar Rp. 1.000.000 dengan ansuran sebesar 115.000/bulannya dalam jangka waktu 10 bulan. Besarnya peminjaman yang diberikan ini disesuaikan dengan bentuk usaha dan kemampuan membayar. Dalam peminjaman berikutnya kelompok diberi batas maksimal untuk meminjam Rp. 2.000.000. bentuk pengembangan usaha RTS seperti warung nasi goren, berjualan Jus buah, sandwhice gerobak dan membuka warung makanan .

Dalam peminjaman yang dilakukan RTS yang tergabung dalam Kelompok Swadaya Masyarakat (KSM) bentuk pembayaran cicilin yang dilakukan RTS model sistem renteng yaitu kelancaran pembayaran satu anggota berpengaruh terhadap anggota lainnya.

Selain peminjaman untuk pengembangan usaha, bentuk peminjaman lainnya seperti kebutuhan pokok untuk KSM juga bisa dilakukan oleh RTS. Hal tersebut menunjukan rendahnya pengawasan dan pemantauan dari pihak pelaksana program dilapangan. Pelaksanaan dilapangan pengelola program juga tidak pernah melihat situasi atau keadaan dilapangan. Pandangan positif terhadap program PNPM-MP yaitu juga memberikan kemudahan dalam peminjaman dana bergulir, dan terlalu memberikan kemudahan ternyata banyak juga masyarakat yang tidak tergolong kelas rumah tangga miskin juga bisa mendapatkan pinjaman ini dipaparkan oleh masyarakat yang menerima dana pinjaman dari program tersebut.

Pinjaman dana bergulir yang dilaksanakan pada masyarakat banyak memberi manfaat bagi masyarakat miskin pada aspek ekonomi, yang dianggap mampu memberikan peluang dalam pengembangan usaha dan kebutuhan pokok keluarga. Terkait dengan masalah kemiskinan yang berhubungan dengan dimensi kemiskinan secara struktural ini salah satunya tampak dari kurang percayanya pihak pelaksana program terhadap RTS terutama bagi yang berpendapatan rendah untuk dipinjami dana karena memandang kurangnya kesanggupan RTS dalam mengembalikan pinjaman yang membuat pelaksana program lebih bersifat selektif dalam menentukan siapa yang layak menerima bantuan, dengan kata lain masih adanya dominasi elit dalam peminjaman dana bergulir PNPM-MP di Kelurahan Balai Gadang yang menyebabkan terjadinya hambatan dalam pengembangan masyarakat miskin. Penegasan mengenai hal ini dapat dilihat dari masyarakat yang memeberikan respon yang negatif pada pelaksanaan PNPM-MP.

\section{KATEGORI RESPON NEGATIF RTS.}

Dalam pelaksanaan program PNPM-MP dana bergulir buat menanggulangi kemiskinan ternyata masih banyak keluarga miskin yang tidak merasakan manfaatnya dari pelaksanaan program tersebut, ini terlihat dari kurang terpetakan KK miskin yang lakukan fasilitator, banyak dari RTS yang belum dapat dana pinjaman. Dari sinilah RTS merasa tidak ada memberikan atau menaiki taraf kehidupan keluarga miskin. Selain itu juga masyarakat memberikan pandangannya pada pelaksanaan program dengan pandangan negatif, dikarenakan RTS yang tergabung dalam Kelompok Swadaya Masyarakat (KSM) yang diputuskan peminjamannya. Banyaknya dari RTS yang tidak membayar cicilan dari kesepakatan yang sudah diberikan kepada RTS. RTS seperti ini memberikan respon yang kurang baik 
kepada pelaksanaan program PNPM-MP, dari semua RTS yang memberikan pandangan nya kurang bermanfaat bagi keluarga miskin, disebabkan tidak sanggup RTS dalam pengelolah uang yang dipinjamkan.

Kebanyakan RTS yang mendapatkan dana bergulir tidak bisa berbuat apa-apa terhadap dana yang didapatkan, dikarenakan RTS tidak bisa mengelola uang, seperti salah satu RTS mendapatkan pinjaman Rp.1.000.000 dan mencoba membuka warung dan hasilnya tidak memberikan keuntungan bagi RTS yang berakhir ketidaksanggupan RTS dalam membayar cicilan perbulan dari kesepakatan yang dilakukan.

Bentuk seperti ini yang mengakibatkan RTS terjebak dengan pinjaman dana bergulir, sekitar $40 \%$ di Kelurahan Balai Gadang terkendala dengan cicilan perbulan, selain itu juga faktor yang menyebabkan ketidakberdayaan dan ketidakmampuan masyarakat miskin untuk merubah nasibnya karena struktur sosial yang berlaku dalam masyarakat Kelurahan Balai Gadang.

Permasalah seperti ini tidak selalu datang dari satu pihak saja, karena apa yang dilakukan oleh pihak pelaksana PNPM-MP nampaknya bukan tidak beralasan, hal ini dilakukan untuk membentuk kesadaran masyarakat bahwa pinjaman yang diberikan bukan sebuah pinjaman cuma-cuma sehingga sering terjadi pemutusan dalam peminjaman apabila terjadi penunggakan, hanya saja pelaksanaannya yang belum tepat karena masih ada masyarakat yang tidak seharusnya mendapatkan pinjaman justru mereka yang lebih menikmati pelasanaan pinjaman dana bergulir dari PNPM-MP serta pelaksanaanya belum sesuai dengan fungsi pemberdaannya belum dilaksanakan.

Selain itu juga terjadi karena pihak pengurus semata-semata hanya ingin menjaga keberlangsungan PNPM-MP di kelurahan mereka dalam aturannya memang ada saksi bagi kelurahan maupun kelompok penerima bantuan jika terjadi penyimpangan dan penunggakan cicilan, dimana untuk periode selanjutnya aspirasi para anggota kelompok yang lain tidak akan diakomodir lagi pada tahap selanjutnya. Satu anggota saja yang tidak membayar maka anggota kelompok yang lain juga akan terkena imbasnya, pelaksana PNPM-MP menyebutnya dengan sistem tanggung renteng.

Pengurus Bantuan Langsung Masyarakat (BLM) sangat berhati-hati dalam memilih orang atau kelompok yang akan dipinjami dana, karena konsekuensinya bagi pihak pengurus harus bersedia menanggulanginya dan harus selalau bersedia melakukan penagihan kepada RTS. Namun walaupun demikian tetap saja para pengurus hendaknya lebih mengutamakan pemberian bantuan kepada mereka yang benar-benar membutuhkan dan upaya pemberdayaan harus benar-benar intensif dilaksanakan.

Apabila dilihat dari masyarakatnya maka masalah kemiskinan di Kelurahan Balai Gadang juga datang dari RTS itu sendiri yang masih memaknai pinjaman yang diberikan bukan sebagai dana stimulus untuk merangsang kreatifitas mereka dalam meningkatkan kesejahteraannya, melinkan masyarakat masih terjebak dalam paradigma yang memaknai pinjaman lebih kepada bentuk "pemberian" dari pemerintah, sehingga merasa berat dalam pengembalian pinjaman yang diberikan.

Paradigma bentuk "pemberian" ini menjadikan RTS malas, pasrah pada keadaan yang ada dan sudah memotivasi diri untuk mau lepas dari keminskinan, hal ini memiliki korelasi dengan apa yang disebut budaya kemiskinan menurut Lewis (Suparlan, 1984) dimana budaya kemiskinan mencakup pada apa yang diyakini (nilai-nilai), respon dalam tindakan (sikap) dan abstraksi-abstraksi dari kelakuan sehingga terbentuk sikap ketergantungan, kuatnya perasaan tidak berharga dan memiliki sikap rendah diri. Selain ditandai dengan sikap yang memaknai pinjaman lebih kepada bentuk "pemberian" bukan kepada stimulus maka juga terdapat perilaku RTS yang memanfaatkan pinjaman untuk kepentingan lain yang menyebabkan sulitnya RTS untuk bisa berkembang dan terlepas dari kemiskinan.

\section{PANDANGAN RTS TIDAK TIDAK KEMBALI TERKATEGORI SEBAGAI SASARAN}

Banyak dari RTS yang tidak masuk dalam kategori untuk peminjaman dana bergulir kembali, padahal mereka mengikuti semua langkah-langkah dalam proses peminjaman hingga semua pembayaran cicilan dibayar tepat waktu. Dalam 
pelaksanaan program PNPM-MP bagi masyarkat yang sudah lebih dua kali dapat pinjaman dana sudah tidak didapatkan lagi untuk meminjam. Dari klarifikasi berdasarkan RTS yang memberikan pandangan yang merespon positif mengenai tidak kembali terkategori sasaran dan sebaliknya.

\section{Kategori pandangan positif tidak kembali terkategori}

Pandagan RTS yang merespon positif mengenai tidak kembali terkategori sebagai sasaran tidak menjadi masalah bagi RTS, dikarenakan RTS sudah merasa usaha yang dikembangkan dari peminjaman dana bergulir bisa dibilang cukup berkembang seperti RTS yang membuka usaha sewa pelaminan, usaha ini sudah cukup berkembang dari modal tiga kali peminjaman, bagi RTS yang sudah memiliki usaha dan cukup berkembang merima positif dari aturan yang diberlakukan pelaksana program yaitu PNPM-MP.

RTS tersebut menyatakan sudah aturan yang disepakati untuk aturan peminjaman hanya berlaku tiga kali peminjaman. Aturan seperti ini dibuat untuk memberikan kesempatan bagi RTS untuk membuka peluang usaha dan juga untuk melepas ikatan kemiskinan pada keluarga miskin di Kelurahan Balai Gadang.

RTS yang mendapatkan pinjaman selama tiga kali peminjaman ini merupakan RTS yang rajin mencicil tepat waktu tidak pernah mengalami tunggakan dalam cicilan, dari keuntungan usaha milik RTS ini bisa untuk biaya pendidikan anak, kebutuhan ekonomi keluarga dan kebutuhan pangan, sandang dan primer.

Pelaksanaan program PNPM-MP ini sudah terealisasi dengan baik, namun hal seperti ini belum bisa melepaskan keluarga miskin untuk keluarga dari kemiskinan yang dirasakan masyarakat di Kelurahan Balai Gadang, dari realisasi program ini masih banyak keluarga miskin yang benar-benar membutuhkan, walaupun secara operasional sudah dilaksanakan sesuai dengan prosedur pelaksanaan program namun masih bersifat formalitas, karena belum mementigkan kepentingan keluarga miskin untuk bisa keluar dari kemiskinan, melainkan baru memberikan modal agar dana pinjaman PNPM-MP bisa digulirkan, sehingga penerima bantuan lebih kepada mereka yang mendapatkan kepercayaan untuk mengembalikan.

\section{Kategori Pandangan Negatif Tidak Kembali Terkategori}

Pandangan RTS yang merespon negatif mengenai tidak kembali terkategori sebagai sasaran menjadi suatu permasalahan yang dirasakan RTS. Kebanyak RTS mengeluh dikarenakan tidak bisa mendapatkan pinjaman lagi dari pelaksana program. RTS ini diberikan sanksi oleh pelaksana program dikarenakan pinjaman yang diberikan tidak memperlihatkan kemajuan usahanya, secara tidak langsung RTS tidak sanggup mencicil dari yang sudah ditetapkan diawal peminjaman.

Kendala dalam mengelola usaha RTS menjadikan RTS masuk kedalam tidak mendapatkan peminjaman kembali. Usaha yang dikembangkan RTS banyak yang gulung tikar atau tidak menunjukan keuntungan dan berakhir penutupan pada usaha tersebut, penutupan usaha ini yang menjadikan susahnya RTS untuk mencicil tunggakannya dari yang disepakati diawal peminjaman.

Seperti usaha berjualan lontong, membuka warung, berjualan pulsa, menjual gorengan, selain usaha yang dikembangkan oleh RTS, ilmu dalam pengelolaan usaha tersebut juga salah satu faktor usaha RTS tidak bertahan lama, ketidaktahuan RTS dalam mengelola uang menjadi penyebab utama terhentinya usaha RTS.

Pelakasana program menghentikan pinjaman dana bergulir diakibatkan keluarga miskin yang meminjam tidak sesuai lagi dari kesepakatan awal yaitu banyaknya tunggakan cicilan dari RTS yang meminjam. Dari kebanyakan RTS yang tidak kembali terkategori ini banyak cendrung pasrah pada keaadaan, dan rendahnya untuk melawan kemiskinan yang dirasakannnya ini menujukan indikasi adanya kebudayaan 
kemiskinan yang melekat pada keluarga miskin.

Pelaksana program juga belum mampu membentuk kesadaran masyarakat untuk bangkit dari kemiskinan, ini ditunjukan pada rendahnya motivasi RTS untuk memaksimalkan bantuan yang berikan berupa peminjaman dana bergulir tanpa dibekali keterampilan untuk mengelolanya. Sedangkan dalam petunjuk teknis operasioanal pinjaman dana bergulir dijelaskan, bahwa pengelola pinjaman bergulir harus berorientasi pada proses pembelajaran untuk penciptaan peluang usaha, kesempatan kerja dan peningkatan pendapatan masyarakat miskin, serta kegiatan produktif lainnnya.

Selain tidak kembali terkategori dalam pelaksanaan program, sebagian RTS juga yang tidak melihatkan usahanya untuk mendapatkan pinjaman dana bergulir, dikarenakan pinjaman akan menjadikan RTS terlilit utang, sehingga RTS yang berpikiran seperti ini tidak akan melanjutkan untuk meminjam dana bergulir tersebut. Namun agak sedikit berbeda dari RTS yang meminjam dan mencicil dengan tepat waktu akan mengharapkan pinjaman berikut dari ketentuan peminjaman yaitu tiga kali, tidak diberikan pinjaman kepada RTS tersebut yang pada akhirnya RTS hanya pasrah melihat ketidakadilan bagi RTS yang mengalami tidak mendapatkan peminjam. Banyak memberikan pandangan adanya ketidakadilan dalam peminjaman yang dirasakan RTS, dikarenakan tidak mendapatkan peminjaman kembali.

Berdasarkan pendekatan teori intrasksionisme simbolik, bahwa pemaknaan tersebut berdasarkan dari interaksi sosial yang diantarai dengan penggunaan simbol-simbol yang ditampilkan dan tindakan yang dilakukan pihak pelaksana program PNPM-MP dalam upaya penanggalungan kemiskinan sehingga terbentuk pemaknaan tindakan oleh RTS. Adapun simbol yang melekat pada PNPM-MP terlihat dari simbol yang dikonsumsikan secara verbal melalui penggunaan bahasa, dalam penelitian ini terlihat dari bagaimana PNPM-MP (LKM, Faskel dan UPK) dalam mengkomuni-kasikan programnya secara verbal yaitu pengalokasian dana dan penentuan RTS lebih ditentukan atas dasar kemampuan membayar oleh RTS selain itu juga didasarkan pada kedekatan dengan pihak pelaksana PNPM-MP walaupun kedekatan ini tidak termasuk kedalam hal yang dikomunikasikan secara verbal namun terlihat dari sikap yang ditampilkan, inilah yang akhirnya dimaknai oleh keluarga RTS yang dalam penelitian ini dikategorikan pada pandangan yang memaknai baik, sedang dan kurang baik.

Salah satu kasus tersebut dari keluarga RTS yang bekerja sebagai pemulung yang benar memanfaatkan pinjaman dana bergulir untuk usaha, usaha yang dibuka adalah berjualan makanan ringan, namun usaha tidak menguntungkan dikarenakan sepi pembeli, sehingga jumlah pemasukan dan keuntungan yang didapatkan sulit untuk ditentukan, karena setiap tidak setiap hari ada pemasukan dari usahanya. Sementara itu mereka harus membayar cicilan sebesar Rp. $115.000 /$ bulan, sedangkan keuntungan perhari yang ia dapatkan tidak bisa digunakan untuk membayar cicilan, karena digunakan untuk kebutuhan sehari-hari, dan berujung pada pemutusan peminjaman inilah yang menjadikan masalah dalam pelaksanaan progaram PNPM-MP.

Selaknya sebuah program pemberdayaan dari awal penyaluran dana seharusnya sudah melakukan pengawasan dan pembinaan terhadap aktifitas usaha keluarga RTS, sehingga dengan pengawasan dan pembinaan tersebut pihak pelaksana program dapat memperjuangkan atau mengupayakan peningkatan volume usaha sehingga keuntungan yang didapatkan lebih besar, hal seperti ini lebih penting guna untuk melepaskan keluarga miskin dari kemiskinan permanen.

\section{KESIMPULAN}

Secara umum pandangan RTS mengenai tidak kembali terkategori sebagai sasaran pelaksanaan PNPM-MP adalah RTS 
memberikan pandangan yang menunjukan menerima posisi mereka sebagai pihak yang sudah tidak bisa menerima dana BLM, terutama bagi angsuran peminjamannya lancar yang telah meminjam hingga tiga kali periode peminjaman, namun RTS yang menunggak hanya menerima dalam satu kali periode peminjaman justru masih mengharapkan bantuan pinjaman dana bergulir dari pelaksana program PNPM-MP, tatapi ada juga yang bersifat apatis karena bantuan yang diberikan tidak memberikan pengaruh yang signifikan terhadap peningkatan tarah hidup mereka.

\section{DAFTAR PUSTAKA}

BPS. (2011). Padang Dalam Angka 2011.

Sumatera Barat: Badan Pusat Statistik. Kementrian Pekerjaan Umum. (2007).
Panduan Umum PNPM Mandiri.

Kementrian PU.

Kementrian Pekerjaan Umum. (2010). Pedoman Pelaksanaan PNPM-Mandiri Perkotaan. Kementrian PU.

Poloma, M. M. (2010). Sosiologi Kontemporer. Jakarta.

Ritzer, G., \& Goodman, D. J. (2010). Teori Sosiologi Modren. Jakarta: Kencana.

Sukron, M. (2009). Pemberdayaan Masyarakat Untuk Mengurangi Kemiskinan Melalui PNPM-Mandiri. Universitas Sunan Kalijaga.

Yulyanti, A. A. (2010). Implementasi Program Nasional Pemberdayaan Masyarakat Mandiri (PNPM-Mandiri) di Kelurahan Cadasari Kab. Pandeglang Periode Tahun 2009. Sultan Ageng Tirtayasa. 
